\title{
IMPACT OF TRUMP POLICIES ON US-EU PARTNERSHIP IN CURRENT AND PROJECTED TIMEFRAME
}

\author{
Fareeha Majeed*
}

\begin{abstract}
After the American elections of 2016, an upset occurred with the victory of Donald Trump as the president of United States of America. From day one, he was in lime light due to his controversial polices and extremist behaviour towards Muslims and other countries of the world. Similarly, he had a very odd behaviour towards European Union and its member countries or in other words it would be accurate to say that he wanted to demolish European Union. In current scenario, EU is facing multidimensional problems in the form refugee crisis from many parts of the world, Russian aggressive policies towards EU, ethnic movements in Europe, and above all critical elections in Italy, France and the Netherlands. Currently, it seems that the whole Europe is at stake and all these circumstances are leading EU towards a huge crisis. It seems that EU is facing the most difficult time period since its emergence. Critics are clearly indicating that $E U$ could only survive with the active participation of France and Germany and that Europe needs serious changes by hearing the voice of the people and can gain its strength back by solving the major issues such as immigration problems and increased terrorism.
\end{abstract}

Keywords: Trump regime, EU and Brexit, US and European Union, Trump regime a potential threat for EU

\section{Introduction}

European Union is considered as the third largest super power of the world. EU integration provided an opportunity to the European nations to come closer under the shield of EU to protect their mutual rights and safeguard their interests. European Union is a leading economic organization of twenty seven member countries. These states are primarily situated in the premises of Europe. In 2009 Treaty of Lisbon came into force which brought latest amendment in EU constitution. EU operates through an organized system of supranational High Authority through decisions which are decided by the member countries. European Union maintained a single European market with the help of an effective system of laws which are equally applied on all the member states. Similarly within the Schengen Area passport control is not compulsory in other words it is abolished. Basic aim of creation of European Union was to make sure the free movement of goods, services and people. Furthermore, European Union sends its Permanent diplomatic missions around the globe. EU also represents Europe in United Nations WTO, G-20 and G8. Creation of Common Foreign and Security Policy was another objective of EU to represent European Union in foreign relations and defence matters.

${ }^{*}$ Fareeha Majeed, Ph.D. Scholar Area Study Centre, University of Karachi 
EU has failed to formulate an effective foreign and security policy to get rid from American influence.

Being a successful economic and political entity, EU flourished a lot in past decades but in recent timeframe EU is facing multidimensional threats. For instance, extremist attacks on Europe, Russian interventions to weaken EU with cyber-attacks and backing far-right political parties by funding and facilitating them. Another most serious and potential threat could be the policies and intentions of Donald Trump who had tried hard to compel EU member countries to leave EU causing disintegration in the region. He further said that Europeans are acting foolish by merging their nationalism under a supranational high authority and putting their political thinking and future organization on nationalist ideas. He supported his view point by indicating the EU problem like, poor economic condition, security issues, migration issues and geopolitical weakness of neighborhood. In his opinion, leaving EU is the golden opportunity for European countries. He also suggested that it would be easier for the member countries to exit from EU first and then they can manage their domestic issues. On the other hand, situation is getting complicated after the withdrawal of UK but future role of UK is still not determined. European parliament had indicated that France, the Netherlands, Austria, Finland and Hungary could leave EU in case of further problems inside the EU. Germany under the leadership of Angela Merkel is also facing serious problems in paying $£ 2.44$ billion annually to maintain budget of EU after Brexit. German government suggested that incase of British cooperation, the future of EU can be protected with the collaboration of France and by making UK an associated partner of EU for further development. In case if EU failed to meet these challenges, it would be very difficult for the survival of EU. One more criticizer of the EU is leader of Poland's ruling party who said that UK referendum result indicated the necessity for improvement in the EU is required. It can be done by introducing a new European treaty based on structural reform. Other European countries like Denmark, Italy, France, the Netherlands, and Sweden are facing serious demand of referendums in their countries. In her statement, German Chancellor Angela Merkel said: "There is no point beating about the bush: today is a watershed for Europe, it is a watershed for the European unification process". The European Commission president, Jean-Claude Juncker, said this does not spell the end of the European Union and the bloc has "decades of experience in overcoming crises". ${ }^{1}$ The Brexit vote can be demanded by other European nations like UK. In recent past Foreign ministers of EU member states met in Berlin to revive the crushed confidence of the inhabitants of European Union.

Trump has an intention to destabilize or deteriorate the EU which will ultimately be beneficial for Russia. Russian president is considering this situation as a softball pitch over the plate for Russia. Apparently it seems that Russia would be more comfortable to deal with a weak EU than individual states. Because Sovereign nations can do more than the lowest common denominator and Trump was intended to weak EU. At the same time the previous regime of US was trying to cooperate very strongly with Europe particularly in terms of sharing intelligence and counter terrorism.

\footnotetext{
${ }^{1}$ Barbara Tasch, There is no point beating about the bush: today is a watershed for Europe, Business Inside, UK, June. 24, 2016
} 
While the current government has not yet expressed a policy based on mutual cooperation and coordination, it is a fact that Trump regime is actively undermining the EU leadership for leaving Europeans under the uncertainty whether the US is a reliable partner or not.

Several researchers and ex politicians are of the views that Europeans must not mistrust European Union and wait for betterment. In this regard, France and Germany can play an active role to restructure and reshape European Union. The former EU diplomat said that it is too early to predict the future of European Union. He pointed out that it's still so early in the Trump administration that the President doesn't yet have in place a full Cabinet that might reflect broader and less ideological views.

\section{Methodology}

The study is designed to identify the problems that currently EU is facing due to Trump regime. It will also highlight the future challenges that Europe could face in projected time frame. Moreover, the impact of Trump regime in the politics of Europe and rest of the world would also be discussed. Secondary data was used in the study which was compiled through publications and journals of history and other authentic sources. Secondary data is a document or recording that relates or discusses information originally presented elsewhere. Secondary sources are research reports that use primary data to solve research problems, written for scholarly and professional audiences. Analytical and descriptive approaches were applied in research. Important factual information based upon historical relation was analysed to explain political and economic environment of Europe and problems faced by EU due to the policies of Trump Regime.

\section{Discussion}

\section{Trump regime, a potential threat for $\mathrm{EU}$}

Emergence of European Union is considered the most significant achievement of this century but current political landscape of world is highly non favourable for the functioning of EU. Recently European Union declared Trump regime as a potential threat for existence of European Union. In current situation the tension growing between US and EU also resulted in deteriorated military and economic relations as well. Current leadership of European Union portrayed the Trump administration as a hazard like Russia, China and terrorism. New American administration is highly aggressive and highly unpredictable. The arrival of new American government brought too much controversial polices which created problems for European Union. American Foreign policy is getting unbalanced and tightening its grip on world politics. ${ }^{2}$

Critics are of the view that current regimes of many European countries are showing their unease about President Donald Trump policies on European institutions. The role of NATO is getting highly controversial and considering it as an obsolete military alliance of Atlantic countries. At the same time the political thinking in US is taking dismissal of

\footnotetext{
${ }^{2}$ http://europa.eu/european-union/documents-publications_en (accessed in March 2017)
} 
EU as a vehicle for Germany and a very bad experience of doing business partnership with the EU. There is another apprehension for EU countries that Trump's regime will not only destabilise the EU, but it will also facilitate Russia, which would prefer a destabilised NATO and a stressed Europe-US partnership. Current Leaderships of European countries are concerned about simulated news and conspiracies about upcoming European elections. While some expert's supporter moved away from the EU and multilateral organizations, many diplomats and analysts assumed the new US government appeared as change in US-EU association in ways that are theoretically weakening. ${ }^{3}$

Trump's strategies for the EU are totally non effective and biased, Every European was concerned expect the US to seek out the international crisis. New US president wouldn't mind at all if the EU fell apart rather he is intentionally drowning the ship of European Union.

\section{Problems and limitations faced by European Union}

After British withdrawal, the whole scenario has been changed. Europeans are still not fully aware about the benefits and drawbacks of European Union. The emerging trends are showing that there are fewer arguments in favour of European integration and most of the world is no more interested in widening EU. It seems that the winds of change are sweeping through Europe and many EU member countries are more interested in determination for autonomy, sovereignty, devolution of power. Similarly, numerous efforts of Trump regime to negatively affect EU are getting faster day by day. Trump appears to be more and more problematic as far as the economic policies of EU are concerned.

Europeans do not want to surrender against those who want to weaken or undermine the transatlantic bond which can affect the global order and peace of the world. In past, both US and Europe moved ahead with their motto which was United we stand, divided we fall. According to a senior adviser for Security and Defence matters of German Marshall Fund, separated Europe and a weaker US-Europe association can cause trouble for the US as well to find future partners to work with mainly on global security issues. There could be an economic consequence that damages US businesses, and at the same time could permit Russia and US to intervene divided Europe.EU relation with the rest of the world are deteriorated and perhaps breaking.

Donald Trump still have to work hard with his Cabinet and he does not have any other option but to accept the decision of the judiciary on many issues and American public opinion is also not in the favour of trump regime they are demonstrating against his extremist polices against Islam and immigration problems. He is probably misleading

\footnotetext{
${ }^{3}$ Kathleen R. McNamara, Trump Takes Aim at the European Union, snapshot, Foreign Affairs, January 24, 2017
} 
because it expresses the views of a very small segment of the society around him and not reflective of the larger group. ${ }^{4}$

In near future, EU must act as a strengthened trading bloc without US and UK or it may be slightly smaller. Economic strength of the EU can make it stronger than the expectation of people. Critics of the EU had an objection on free movement of people, capital and establishment of free market. Moreover, transnational supply lines and free movement act is source of tension for the Trump regime.

In the same way, other EU countries are also facing serious challenges. For instance, French economy is in continuous deterioration for recent years. Overlooking the difficulties is not an accurate option. The economic condition is not growing in last five years and will even contract marginally in recent years. According to statistics, approximately 3.26 million Frenchmen are still jobless. People are having low standard of living and purchasing power of consumer has declined over the period of time has declined.

Beside the fact that France is that the fifth-largest economy of the world at present but at the same time interest rates of the government bonds are continuous declining in recent few months. It seems that country is moving fast towards the bankruptcy and simply cannot be compared with other European countries like Italy, Spain and Sweden. France seems to be weak. France is continuously moving towards to deterioration and its responsibility is stirring towards Germany. Germany without the support of France cannot transfer Euro to France and at the same time France has to act as the major leading partner along with Germany. Another serious problem is that France is losing grip in the matters of European Union. According to the study of Pew Research Centre, the community support of the EU in France has failed from 60 to 41 percent in the political matters of European Union during past one year. It seems that in near future, Brussels will be gradually handling France more as a problematic but not as one of Europe's supportive pillars. No one can exactly figure out the problem of French political instability. French government debt has increased to more than 90 percent of the gross domestic product. It is Germany's fault that, for past few years, French governments have remained unsuccessful to make the country's business situation more reasonable. Currently, France may be in very deplorable condition but it still has a lot going for it. ${ }^{5}$

Recently, France introduced new immigration laws in the country. These new immigration laws based upon migration rules. These new laws are hard to be implemented. It introduces different types of punishments like integration contract, moreover detention before expulsion longer and also introduced fingerprinting to all the residents and ones requesting for visas or dwelling papers. Immigrants develop working tools to labour market, but they are invisible people who hold no rights. There are numerous problems, one of them is the minimum rights for the foreigners particularly migrants who are permanently living in France. A new principle has been adopted by

\footnotetext{
${ }^{4}$ Kate McCann,EU leaders attack Donald Trump saying 'we won't be trampled on' and warn of impact on the bloc's future relations with US, The Telegraph, $4^{\text {th }}$ February 2017

${ }^{5}$ Kiosk Hwang, Towards New Economic Cooperation in Northeast Asia; Lessons from the Franco-German Coalition, Contemporary European Studies', Vol. 25, No.3 .2007.
} 
Parliament that anyone form 1984, who are living in France for at least ten years must have their stable residence cards issued. This new law established that residence cards holders won't any longer but integration will be the only condition to the issuance of papers.

Germany is considered the significant country of central Europe and it is much better than other European countries as far as the political and economic stability is concerned. Moreover, it has high tax revenue ratio in recent years. It was the one feature of the picture. Many federal countries are severely in debt. As a result of that many big cities and metropolises are broken. ${ }^{6}$

Another problem that German nation is facing right now is the unequal opportunities to get education to different income groups. For instance, each and every child must have equal chance to get better education, but in reality in Germany all the children do not have the same rights of education. One more issue which is faced by Germany in current time period is fair wages and salaries to the employees and labour class. There are so many individuals who effort all day long, but get such low salaries that they can't make a living off it. Due to this particular reason there have been many opinions in support of minimum income for all workers in Germany. Germany requires finding well deal with its vigour requirement. Moreover, the German health system is a source of attention, there are also discriminates in it for instance those who have a reserved insurance plan acquire improved medical cure as well. As a matter of fact, nobody is able to pay for the care of the old and the sick. In case of increase in numbers of elder people on the other hand the number of young people paying for their health services. Another most important area is energy. On the energy front, Germany succeeded and continuing since determining to meet the challenges of atomic energy and shift to other sources indelicately in past two years. Germany's energy requires meeting via solar panels, biogas planes, and wind turbines. Germany ambition is to meet the entire energy requirement as early as possible but the problem that is faced by German government is that they don't have enough pipes to transport electricity where it is required. In addition to that, it is a fiscal strain on German people. Generation of electricity from renewable energy sources is to some extent supported through extra charges by electricity consumers. In case of the more environment protected electricity being produced, it will cause more charges. The energy producing planes are also been analysed for granting exemptions toward many companies, mainly those in energy intensive productions that are internationally inexpensive.

As a result of crisis of Syria, a large number of refugees became a problem particularly for European countries. Their rehabilitation and settlement was necessary for international peace and stability. Similarly, Germany also adopted a flexible refugee policy for a large figure number of Germans refugees were on the top priority on Germany's agenda after Syrian crisis. Huge number of refuges came near the borders of Europe and Germany was ready to accommodate them. Primarily, Germany was prepared

\footnotetext{
${ }^{6}$ Grenville, John Ashley Soames. A History of the World from the 20th to the 21st Century. (Rutledge Press 2005). pp. 370-371

${ }^{7}$ John McCormick, The European union politics and polices: (West View Press, 2008), p.27
} 
to accommodate 5,000 refugees. But the problem was where to accommodate them. In particular area, inhabitants of Germany are getting hostile against the policy of accommodating refugees. Moreover, the issue which was highlighted a lot was the maintenance of the law that immigrants were not allowed to vacate their living area without prior permission and they are not allowed to earn their livelihood. A huge number of immigrants have been disparate of this policy, domestic debt, Euro crisis, education, fair, salaries, health care energy and Syrian crisis all are significant national issues that will have to be undertook in the next few years.

Trump regime is trying to establish bilateral trade contracts with member states, he is trying to legalize many controversial polices because many trade conferences have to be done through the EU capital in Brussels. In future, Trump may simply try to avoid dealing much with EU leaders. He is clearly going to talk to the capitals of the bigger states and if he runs into difficulties will try to play one off the other. ${ }^{8}$

\section{EU after Brexit}

British withdrawal from European Union is the turning point of the history. It left a deep rooted impact not on the politics of Germany but on the rest of the world as well. Consequences of the British removal can be seen in the whole Europe. In this regard, Berlin's establishment took many initiatives particularly in the field of security and economics which are considered the key sectors in the Germany. Similarly, in that context, British voters withdrew from their nation's 43-year relationship with EU. Germany declared strategies to enlarge its armed forces strength in 25 years. Simultaneously, Berlin silently started growing its participation in international armed assignments. Recently, German armed forces were just 180,000 soldiers and if it is compared with the time of re-unification in 1990, it was 600,000. Germany's new immigrant labour policy was introduced after Brexit. To coup up the Germany's economic challenges, they must formulate a sustainable economic policy. After referendum result, German Chancellor Angela Merkel, signifying that life by separating Germany by EU should not be more valued than life inside.

Ms Merkel argued that having EU benefits, such as entrance to the single market of 500 million consumers, was impossible without accepting responsibilities like permitting for the free movement of people. Berlin's strategies seem to be allowance of the development led in recent years by Ms Merkel, anticipated at fragment away at the control of Brussels and improving the role of national leaders in EU policymaking.

Similarly, Brexit also had influence on France. French government executed that tax in the nation. The government imposed necessary taxes on immigrants as well. They are guaranteed to make it firmer for Brits to get occupations, totally given the fact France is under burden to cut joblessness. People with lots of practices will maybe be alright, but for those who come over to work in bars or in removals or as an estate agent. People who

\footnotetext{
${ }^{8}$ Brinker, Benedikte, Cultural foundations of the common foreign and security policy of the European Union: the case of Britain, Denmark and Germany (Copenhagen: Copenhagen Political Studies Press, 2004)
} 
say a Brexit would mean Britain can retain all the supports of living in the EU and just lose the difficulties are breathing in a fairy land.

\section{Conclusion}

Donald Trump along with his chief strategist, Steve Bannon, prepared to break up the European Union. They also compelled to Germany and France to set the platform to exit European Union through referendums. According to Guy Verhofstadt, who is the European parliament's chief Brexit negotiator, claimed that in current scenario Trump regime is the major threat to the EU other than Russian extremism. ${ }^{9}$ Trump regime symbolizes a potential threat to the European Union Existing projects and European principles. The ex-Belgian Prime Minister and leader of the European liberal group considered trumps initiatives as a disastrous move regarding Trump's call to return to nationalism by leaving European Union. According to Trump, people of the member countries may not accept the reality that EU must disintegrate or will take it as a disaster. $\mathrm{EU}$ is the cause of death of thirty million people due to the ethnic cleansing in Europe.

In spite of common goals, in recent times they worked hard on major policy areas but growing economic difference caused mistrust among them. To renew the bilateral partnership, Germany is required assurances of France to restructuring its development and become a strong economic entity again. In the same way, France required some assurance from Germany for the constancy in Euro area and that Germany will not be failed its special association with France. Most of the European expert's emphasis the significance of Franco-German reconciliation and claim for the importance of European experience to apply in East Asia like china and Japan.

Franco-German reconciliation has not only played role in EU integration but also for the rest of countries as a classic example to be followed to minimize the threat of war among the member countries. It is a fact that EU played an effective role in maintaining cooperation among the member countries for decades but in current time period. It is losing its grip on EU affairs but still an example for world to settle down the dispute and to maintain economic and political stability and harmony among the European countries.

\footnotetext{
${ }^{9}$ Patric Wintour, Brexit negotiator warns Donald Trump poses 'third threat' to EU, The Guardian, 30 January
} 2017 